\title{
Implementasi Manajemen Kesiswaan dalam Meningkatkan Prestasi Siswa MA Unggulan Mamba’ul Huda Krasak Tegalsari Banyuwangi
}

\author{
Moh. Harun Al Rosid', Istiqomah ${ }^{2}$ \\ e-mail : harun2939@gmail.com ${ }^{1}$, istiq7182@gmail.com² \\ Prodi Manajemen Pendidikan Islam \\ Institut Agama Islam Darussalam Blokagung Banyuwangi
}

\begin{abstract}
The objectives of this study were: (1) To determine the implementation of student management at MA Unggulan Mamba'ul Huda Krasak Tegalsari for the 2019/2020 Academic Year; (2) To determine the achievements of MA Featured students Mamba'ul Huda Krasak Tegalsari for the 2019/2020 academic year; (3) To find out the inhibiting factors and supporting factors of student management in improving the achievements of MA MA Mamba'ul Huda Krasak Tegalsari 2019/2020 Academic Year. In this research, using a qualitative descriptive method with data collection techniques using observation, interviews, and also documentation. Data analysis using analysis: (1) data reduction, (2) presentation of data, and (3) drawing conclusions and validity used is data triangulation. The results of this study indicate that: (1) Planning for new student admissions is done one year earlier; (2) New student orientation is held for 3 days; (3) Implementation of student disciplinary coaching involves $B P / B K$ and coordinator of extracurricular activities; (4) Development of intracuricular activities (academic) is done by providing additional lessons; (5) coaching for extracurricular (non-academic) activities is carried out through developing interest talents. In general, the academic achievement of MA Unggul Mamba'ul Huda Krasak Tegalsari students from year to year continues to increase, in the semester examinations there are no students who do not advance the grade. At the time of the National Examination there were no students who did not pass. Supporting factors for student management in improving student achievement include: 1) adequate educational facilities and infrastructure; 2) High student enthusiasm for learning; 3) professional educators; 4) Educators and education personnel come from Islamic boarding schools. Meanwhile, the inhibiting factors are: 1) sharing of learning time with time in dormitories; 2) lack of student discipline. Keywords: Student Management, Student Achievement
\end{abstract}

\section{Abstrak}

Tujuan dari penelitian ini adalah : (1) mengetahui pelaksanaan manajemen kesiswaan di MA Unggulan Mamba'ul Huda Krasak Tegalsari; (2) mengetahui prestasi siswa MA Unggulan Mamba'ul Huda Krasak Tegalsari; (3) mengetahui faktor penghambat dan faktor pendukung manajemen kesiswaan dalam meningkatkan prestasi siswa MA Unggulan Mamba'ul Huda Krasak Tegalsari. Jenis penelitian ini adalah deskriptif kualitatif dengan teknik pengumpulan data menggunakan observasi, wawancara, dan juga dokumentasi. Analisis data yang digunakan adalah: (1) Reduksi Data, (2) Penyajian Data, dan (3) Penarikan Implementasi Manajemen Kesiswaan dalam Meningkatkan Prestasi Siswa MA Unggulan Mamba'ul Huda Krasak Tegalsari Banyuwangi

Moh. Harun Al Rosid, Istiqomah 
JMPID ( Jurnal Manajemen Pendidikan Islam Darussalam )

Jurnal Manajemen Pendidikan Islam

Volume: 2, No: 2, September 2020

ISSN : 2722-7146 (online)

Kesimpulan serta keabsahan yang digunakan adalah triangulasi data. Hasil penelitian ini menunjukkan bahwa: (1) Perencanaan penerimaan siswa baru dilakukan satu tahun sebelumnya; (2) Orientasi siswa baru diselenggarakan selama 3 hari; (3) Pelaksanaan pembinaan kedisiplinan siswa melibatkan BP/BK serta kordinator kegiatan ekstrakurikuler; (4) Pembinaan kegiatan intrakurikuler (akademik) dilakukan dengan memberikan pelajaran tambahan; (5) pembinaan kegiatan ekstrakurikuler (non akademik) dilaksanakan melalui pengembangan bakat minat. Prestasi akademik pada siswa MA Unggulan Mamba'ul Huda Krasak Tegalsari secara umum dari tahun ke tahun terus meningkat, dalam ujian semester tidak ada siswa yang tidak naik kelas. Pada saat Ujian Nasional tidak ada siswa yang tidak lulus. Faktor pendukung manajemen kesiswaan dalam meningkatkan prestasi siswa meliputi : 1) Sarana dan prasarana pendidikan yang memadai; 2) Semangat belajar siswa yang tinggi; 3) tenaga pendidik profesional; 4) Tenaga pendidik dan kependidikan berasal dari pondok pesantren. Sedangkan faktor penghambatnya adalah: 1) pembagian waktu pembelajaran dengan waktu di asrama; 2) kurangnya kedisiplinan siswa.

Kata Kunci : Manajemen Kesiswaan, Prestasi Siswa

\section{A. PENDAHULUAN}

\section{Latar Belakang Masalah}

Pendidikan di madrasah mempunyai peranan penting dalam membentuk watak manusia. Dari ketidaktahuan menjadi tahu, dari kebodohan menjadi kepintaran, dan pendidikan juga dapat membentuk manusia agar tidak hanya cerdas dalam segi pengetahuan saja, tetapi juga harus bertakwa kepada Tuhan Yang Maha Esa, berperilaku mulia, memiliki rasa tanggung jawab, dan beretika yang baik terhadap sesama manusia. Hal ini sesuai dengan yang terkandung dalam Undang-Undang Republik Indonesia Nomor 20 Tahun 2003 tentang Sistem Pendidikan Nasional bahwa, pendidikan nasional berfungsi mengembangkan kemampuan dan membentuk watak serta peradaban bangsa yang bermartabat dalam rangka mencerdaskan kehidupan bangsa.

Manajemen kesiswaan merupakan salah satu komponen yang dibutuhkan dalam penyelenggaraan pendidikan karena siswa merupakan subyek dalam proses pembelajaran di sekolah. Seperti yang telah diungkapkan oleh Mulyasa (2005:168) manajemen kesiswaan adalah penataan dan pengaturan terhadap kegiatan yang berkaitan dengan siswa mulai masuk sampai dengan keluarnya siswa. Disisi lain Mantja (2007:35)

Implementasi Manajemen Kesiswaan dalam Meningkatkan Prestasi Siswa MA Unggulan Mamba'ul Huda Krasak Tegalsari Banyuwangi

Moh. Harun Al Rosid, Istiqomah 
menyatakan bahwa manajemen kesiswaan merupakan segala hal yang berkaitan dengan siswa, mulai dari perencanaan penerimaan siswa, pembinaan siswa selama di sekolah, sampai dengan siswa menyelesaikan pendidikanya dalam proses pembelajaran yang efektif. Sementara itu, Mulyono (2008:178) mengemukakan bahwa manajemen kesiswaan adalah seluruh kegiatan yang mencakup kegiatan pembinaan secara kontinu terhadap siswa agar dapat mengikuti proses pembelajaran yang efektif dan efisien. Dengan demikian, manajemen kesiswaan adalah seluruh proses kegiatan yang terpusat kepada pengaturan, pengawasan, serta pembinaan siswa di dalam maupun di luar kelas agar dapat mengikuti pembelajaran yang efektif dan efisien.

Pendidikan yang menyenangkan dan menggembirakan adalah pendidikan yang berkaitan dengan pemberian pelayanan yang baik, yaitu pelayanan yang sesuai dengan kebutuhan siswa. Dengan demikian, secara mandiri siswa akan bergairah dan memiliki minat yang tinggi dalam belajar, mengerjakan tugas-tugas dari guru dengan senang, dan tidak akan meninggalkan kelas sebelum waktunya. Hal-hal tersebut sangat berpengaruh terhadap prestasi siswa yang juga akan berkaitan dengan masa depanya. Siswa dapat memandang masa depan dengan berfikir apa yang akan diinginkan dan apa yang akan dilakukan untuk mendapatkanya. Kaitan dengan pandangan masa depan dapat diperhatikan pada ayat AlQur'an sebagai berikut :

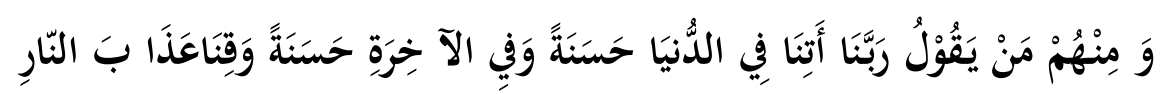

Artinya : “Dan diantara mereka ada orang yang berdo'a : Ya

Tuhan kami, berilah kami kebaikan di dunia dan kebaikan di akhirat dan peliharalah kami dari siksa api neraka". (Q.S

Al-Baqarah:201)

Ayat di atas disebut juga dengan do'a sapu jagat. Karena khasiat dari do'a ini mencakup seluruh keinginan agar sukses di dunia maupun di akhirat. Lafadz fiiddunya khasanah yang berarti kebaikan di dunia mencakup keinginan-keinginan masalah dunia misalnya, kesehatan, tempat tinggal, 
rizki yang melimpah, anak shalih, ilmu yang manfaat, kendaraan yang nyaman, dan lain sebagainya. Hal-hal tersebut sangatlah diperlukan dalam menjalani kehidupan di dunia dan akan memengaruhi masa depan.

Prestasi merupakan hasil yang telah diperoleh dalam suatu kegiatan pembelajaran. Tu'us (2004:76) menjelaskan bahwa prestasi belajar siswa terfokus pada nilai yang diperoleh siswa selama proses pembelajaran di sekolah. Prestasi tidak dapat dihasilkan jika seseorang tidak melakukan sesuatu, bahkan seseorang harus memiliki keuletan dan ketelatenan untuk mendapatkan prestasi. Menurut Hamdani (2011:137) prestasi adalah hasil dari kegiatan yang telah dikerjakan secara individu maupun kelompok. Sedangkan Saiful Bahri (2012:21) menjelaskan prestasi merupakan hasil dari kegiatan yang telah dilakukan yang sifatnya menyenangkan serta dapat dibanggakandengan apa yang diperoleh dalam bidang keahlian tertentu. Dengan demikian prestasi merupakan hasil yang diperoleh siswa dari kegiatan dan keuletan yang dikerjakan secara mandiri maupun kelompok.

MA Unggulan Mamba'ul Huda Krasak Tegalsari merupakan madrasah yang berada dibawah naungan yayasan pondok pesantren Mamba'ul Huda Krasak Tegalsari Banyuwangi. Madrasah ini berdiri sejak 22 Juli 2009 yang hingga saat ini dipimpin oleh Bapak Muhyidin, S.Sos. yang merupakan putra dari pengasuh pondok pesantren Mamba'ul Huda Krasak Tegalsari Banyuwangi. Madrasah ini unggul dalam mengantarkan anak didik menjadi insan yang unggul dunia dan unggul di akhirat. MA Unggulan Mamba'ul Huda Krasak Tegalsari Banyuwangi adalah salah satu madrasah swasta yang ada di kecamatan tegalsari dan satu-satunya yang telah menerapkan sistem pendidikan berdasarkan pada sistem pendidikan terpadu (integrated education) yang komprehensif, dalam : 1) keterpaduan kurikulum, yakni memadukan antara mata pelajaran umum dan agama islam; 2) keterpaduan sistem, yaitu memadukan sistem pendidikan non formal ala pondok pesantren; 3) keterpaduan Pembina aspek kognitif (pengetahuan), afektif (sikap), dan psikomotorik (perilaku) dalam kehidupan keseharian; serta 4) keterpaduan antara sistem 
pendidikan dari kearifan khazanah budaya lokal dengan sistem pendidikan modern yang berbasis sarana pendidikan dengan teknologi modern.

Peneliti memilih MA Unggulan Mamba'ul Huda Krasak Tegalsari Banyuwangi sebagai obyek penelitian adalah karena sekolah ini merupakan sekolah yang bercirikan islami, data dari KEMENAG Banyuwangi menmaparkan bahwa terdapat beberapa madrasah terbaik di Banyuwangi, diantaranya ada 4 madrasah Negeri dan 42 madrasah swasta. MA Unggulan Mamba'ul Huda Krasak Tegalsari merupakan salah satu diantara madrasah terbaik yang ada di Banyuwangi. Dalam program kelanjutan lulusan, hampir setiap tahunya lulusan MA Unggulan Mamba'ul Huda Krasak Tegalsari Banyuwangi melanjutkan pendidikan ke perguruan tinggi baik swasta maupun negri. Baru-baru ini MA Unggulan Mamba'ul Huda Krasak Tegalsari Banyuwangi kembali menorehkan prestasi dalam Stikes Banyuwangi English Competition dengan jenis perlombaan story telling dan presentation skill. Selain memperoleh prestasi dalam bidang akademik, MA Unggulan Mamba'ul Huda Krasak Tegalsari Banyuwangi juga dibanjiri prestasi non akademik, yaitu dalam bidang ekstrakurikuler yang ada di madrasah. Tentunya prestasi-prestasi yang telah diraih tidak lepas dari adanya manajemen komponen yang baik.

MA Unggulan Mamba'ul Huda Krasak Tegalsari Banyuwangi mengalami perkembangan yang cukup pesat, hal ini dibuktikan dengan peningkatan kuantitas siswa pada setiap tahun ajaran baru. Namun dari segi manajerial, berdasarkan pemaparan bapak A. Tri Wahyudin, S.Pd.I. selaku WKM Kesiswaan MA Unggulan Mamba'ul Huda Krasak Tegalsari Banyuwangi ada beberapa kesenjangan yang dapat memengaruhi kualitas atau prestasi siswa diantaranya sebagai berikut :

“...........75\% dari jumlah siswa di MA Unggulan Mamba'ul

Huda Krasak Tegalsari Banyuwangi bertempat di asrama, kebanyakan dari mereka merangkap dikepengurusan sehingga waktu berangkat sekolah anak-anak banyak yang malas. Masalah yang juga sering kami hadapi yaitu adalah karena banyaknya siswa sehingga kami tidak bisa menjangkau dan 
memberi motivasi kepada anak-anaksatu persatu, dan itu juga akan menghambat prestasi mereka. Yang selanjutnya adalah kurangnya fasilitaspendidikan. ini juga sangat memengaruhi prestasi belajar, suatu contoh ruang kelas kami yang masih apa adanya sehingga anak-anak merasa kurang semangat dalam belajar. Masih banyak sebenarnya yang dapat menghambat prestasi anak-anak, misalnya anak-anak yang dari luar atau yang tidak menetap di asrama, saat mereka berangkat dari rumah ke madrasah, tetapi faktanya mereka tidak sampai ke madrasah. Bisa jadi mereka main ke rumah temanya, atau bahkan ke warnet."

Berdasarkan latar belakang di atas, peneliti bermaksud untuk melakukan penelitian dengan judul "Implementasi Manajemen Kesiswaan Dalam Meningkatkan Prestasi Siswa MA Unggulan Mamba'ul Huda Krasak Tegalsari Banyuwangi Tahun Pembelajaran 2019/2020".

\section{Rumusan Masalah}

a. Bagaimanakah pelaksanaan manajemen kesiswaan di MA Unggulan Mamba'ul Huda Krasak Tegalsari Banyuwangi Tahun Pembelajaran 2019/2020?

b. Bagaimanakah prestasi siswa MA Unggulan Mamba'ul Huda Krasak Tegalsari Banyuwangi Tahun Pembelajaran 2019/2020?

c. Apa saja faktor pendukung dan penghambat manajemen kesiswaan dalam meningkatkan prestasi siswa MA Unggulan Mamba'ul Huda Krasak Tegalsari Banyuwangi Tahun Pembelajaran 2019/2020?

\section{Manfaat}

a. Manfaat Teoritis

1) Untuk menambah wawasan tentang manajemen kesiswaan dalam meningkatkan prestasi siswa.

2) Menambah wawasan bagi perkembangan manajemen kesiswaan dalam pengelolaan lembaga pendidikan.

b. Manfaat Praktis

Implementasi Manajemen Kesiswaan dalam Meningkatkan Prestasi Siswa MA Unggulan Mamba'ul Huda Krasak Tegalsari Banyuwangi

Moh. Harun Al Rosid, Istiqomah 
1) Menambah wawasan bagi peneliti dalam bidang manajemen kesiswaan dalam meningkatkan prestasi siswa.

2) Dapat dijadikan bahan pengetahuan bagi pengembangan pengelolaan manajemen kesiswaan dalam lembaga pendidikan baik negri maupun yang swasta.

\section{B. LANDASAN TEORI}

\section{Manajemen Kesiswaan}

Prihatin (2011: 4) mengemukakan bahwa manajemen siswa merupakan pengaturan terhadap siswa mulai dari siswa masuk ke sekolah, sampai mereka lulus. Oleh karena itu manajemen kesiswaan diharapkan dapat menjadi pondasi dalam mengembangkan potensi siswa. Menurut Mulyasa (2007: 45-46) manajemen kesiswaan merupakan salah satu bidang operasional MBS. Manajemen kesiswaan bukan hanya berbentuk pencatatan data siswa, melainkan meliputi aspek yang lebih luas yang dapat membantu upaya pertumbuhan dan perkembangan siswa melalui proses pendidikan di sekolah. Berikut ruang lingkup manajemen kesiswaan :

a. Analisis kebutuhan siswa, yaitu penetapan siswa yang dibutuhkan oleh lembaga pendidikan dengan merencanakan jumlah siswa yang akan diterima dan menyusun program kegiatan sekolah;

b. Rekruitmen siswa, merupakan proses pencarian dan pemikatan siswa yang mampu untuk mendaftar sebagai calon siswa pada suatu lembaga pendidikan dengan melalui tahapan-tahapan tertentu;

c. Seleksi siswa, adalah kegiatan pemilihan calon siswa untuk menentukan diterima atau tidaknya calon siswa menjadi siswa di lembaga pendidikan tersebut dengan berdasarkan ketentuan yang berlaku;

d. Orientasi siswa baru, yaitu kegiatan penerimaan siswa baru dengan mengenalkan situasi dan kondisi tempat siswa menempuh pendidikan;

e. Penempatan siswa, langkah ini disebut juga dengan pembagian kelas. sebelum mengikuti proses pembelajaran siswa dikelompokkan dalam 
kelompok belajar terlebih dahulu. Pengelompokkan siswa sebagian besar didasarkan pada system-sistem kelas;

f. Pembinaan dan pengembangan siswa, langkah ini dilakukan agar siswa mendapatkan bermacam-macam pengalaman belajar untuk bekal kehidupanya di masa yang akan datang. Dalam hal ini, siswa harus melakukan bermacam-macam kegiatan;

g. Pencatatan dan pelaporan, kegiatan ini dilakukan mulai sejak siswa diterima di sekolah sampai mereka lulus atau meninggalkan sekolah;

h. Kelulusan dan alumni, kegiatan ini merupakan kegiatan paling akhir dari proses manajemen siswa. Setelah siswa mengikuti seluruh proses pendidikan dan berhasil lulus, maka akan diberikan surat keterangan lulus atau sertifikat atau disebut juga dengan STTB.

Hadiyanto, (2014:155) memaparkan bahwa pembinaan kesiswaan adalah upaya sekolah (menengah) melalui kegiatan-kegiatan siswa di luar jam pelajaran di kelas agar siswa mendapatkan bermacam-macam pengalaman belajar untuk bekal kehidupan di masa yang akan datang. Beberapa hal yang berhubungan dengan pembinaan kesiswaan adalah :

1) Pembinaan Kedisiplinan Siswa;

2) Pembinaan Kegiatan Akademik (intrakurikuler);

3) Pembinaan Organisasi Siswa Intra Sekolah (OSIS);

4) Pembinaan Kegiatan Non Akademik (ekstrakurikuler);

5) Evaluasi Kegiatan Belajar.

\section{Prestasi Siswa}

a. Prestasi Akademik

Djamarah (2002), memaparkan bahwa prestasi akademik merupakan hasil yang diperoleh berupa kesan-kesan sebagai hasil akhir dari aktivitas belajar. Dalam hal ini menurut menurut Djiwandono, (2002) fungsi dari penilaian prestasi akademik yaitu sebagai berikut :

1) Untuk mengetahui taraf kesiapan siswa dalam menenpuh tingkat pendidikan tertentu. Informasi ini sangat berharga juga bagi pendidik dalam memberikan pengajaran kepada siswa di dalam kelas;

Implementasi Manajemen Kesiswaan dalam Meningkatkan Prestasi Siswa MA Unggulan Mamba'ul Huda Krasak Tegalsari Banyuwangi

Moh. Harun Al Rosid, Istiqomah 
2) Untuk mendapatkan informasi dalam memberikan bimbingan tentang jenis pendidikan yang terkait dengan potensi yang dimiliki oleh siswa tersebut. Bedasarkan potensi yang dimiliki siswa dapat diramalkan jurusan apakah yang paling cocok untuk siswa tersebut. Karena dengan penilaian akademik dapat dihindari adanya salah pilih dalam pemilihan jurusan;

3) Untuk membandingkan apakah prestasi yang dicapai oleh siswa sesuai dengan kapasitasnya. Jika dalam suatu mata pelajaran siswa memperoleh nilai yang lebih rendah dari kapasitasnya, maka perlu dicari fakor penghambat agar siswa dapat mencapai prestasi sesuai dengan kapasitasnya;

4) Untuk mengadakan seleksi, dalam memperoleh siswa siswi pada jenis pendidikan tertentu, maka perlu diadakan seleksi terhadap calon siswa. Hasil penelitian yang dilaksanakan dapat memberikan gambaran yang cukup jelas mana calon siswa yang memenuhi syarat untuk jenis pendidikan tersebut.

b. Prestasi Non Akademik

Menurut Mulyono (2008:188) prestasi non akademik adalah kemampuan yang dicapai siswa diluar jam pelajaran. Prestasi non akademik merupakan kegiatan yang dilaksanakan diluar ketentuan yang telah ada dalam kurikulum serta dijadikan sebagai wadah bagi siswa dalam mengembangkan potensi yang dimiliki. Kegiatan non akademik ini disebut juga kegiatan ekstrakurikuler yang diselenggarakan pada diluar jam pelajaran atau tatap muka. Menurut Supriatna, (2010:3) dalam melaksanakan kegiatan ekstrakurikuler, harus mencapai beberapa fungsi, yaitu:

1) Pengembangan, fungsi pengembangan berguna untuk mengembangkan potensi, bakat, dan minat siswa;

2) Sosial, fungsi ini berkenaan untuk mengembangkan kemampuan dan rasa tanggung jawab sosial siswa;

3) Persiapan karir, yaitu berfungsi untuk mengembangkan kesiapan karir bidang ekstrakurikuler yang dipilih oleh siswa.

Implementasi Manajemen Kesiswaan dalam Meningkatkan Prestasi Siswa MA Unggulan Mamba'ul Huda Krasak Tegalsari Banyuwangi

Moh. Harun Al Rosid, Istiqomah 


\section{Faktor-Faktor yang Memengaruhi Prestasi Siswa}

Menurut Dalyono (2005) faktor-faktor yang memengaruhui prestasi siswa digolongkan menadi dua, yaitu faktor internal dan faktor eksternal.

a. Faktor internal yang memengaruhi prestasi belajar pada siswa meliputi :

1) Kesehatan

2) Intelegensi dan bakat

3) Minat dan Motivasi,

4) Cara Belajar

b. Faktor eksternal yang memengaruhi prestasi belajar adalah :

1) Faktor lingkungan keluarga

2) Faktor lingkungan sekolah

3) Kompetensi guru dan siswa

4) Kurikulum dan metode mengajar

\section{Penelitian Terdahulu}

Berdasarkan penelitian terdahulu terkait dengan tema manajemen kesiswaan dalam meningkatkan prestasi siswa adalah sebagai berikut :

Mualamah (2016) dengan judul Manajemen Kesiswaan Dalam Upaya Meningkatkan Prestasi Siswa studi multi kasus di MTs Negeri Tulungagung dan SMP Negeri 1 Tulungagung. Hasil penelitian ini adalah : (1) penerimaan siswa baru yang mencakup (a) sistem penerimaan, pembentukan panitia PSB, menentukan jumlah kuota siswa; (b) sistem penerimaan siswa dilakukan dengan sistem promosi melalui try out bagi siswa SD/MI; (c) penerimaan siswa baru berdasarkan daya tampung; (d) prosedur penerimaan siswa melalui kepanitiaan PPDB. (2) pengelompokkan siswa terdiri dari: (a) pengelompokkan dalam kelas-kelas berdasarkan jalur yang dipilih yaitu kelas unggulan, regular, dan kelas prestasi; (b) pengelompokan siswa berdasarkan kemampuan dari tes diagnostik; (c) pengelompokkan siswa berdasarkan bakat dan minat dalam kegiatan ekstrakurikuler. (3) pelaksanaan pembinaan kesiswaan terdiri dari: (a) pembinaan kedisiplinan siswa dengan adanya tata tertib siswa, dan adanya reward serta punishment; (b) pembinaan akademik meliputi pengajaran menggunakan KTSP dan K-13, memberikan jam tambahan 
pelajaran, kerjasama dengan lembaga bimbingan belajar; (c) pembinaan non akademik melalui kegiatan ekstrakurikuler untuk mengembangkan bakat dan minat siswa. (4) implikasi manajemen kesiswaan terhadap prestasi siswa adalah tidak lepas dari pelaksanaan manajemen kesiswaan melalui bimbingan dan pembimbing waka kesiswaan, waka kurikulum, guru, wali kelas, guru BP dan tim pengembangan diri dan keahlian.

Halim (2016) dengan judul Manajemen Kesiswaan Dalam Mengembangkan Potensi Siswa Melalui Ekstrakurikuler (Studi Multikasus di Madrasah Aliyah Negeri 3 Malang dan Sekolah Menengah Atas Negeri 10 Malang Leadership Academy). Hasil dari penelitian ini adalah : (1) pengembangan potensi siswa dilaksanakan dengan memberikan ruang berkembangnya potensi dan fasilitas bagi siswa untuk mengembangkan hard-skilldan soft-skill melalui kegiatan ekstrakurikuler; (2) kegiatan ekstrakurikuler bersifat terintegritas dengan kurikulum satuan pendidikan yang dikelola khusus oleh bidang kesiswaan yang bekerjasama dengan bidang kurikulum; (3) Dampak ekstrakurikuler bagi satuan pendidikan adalah memberikan dan meningkatkan keunggulan satuan pendidikan. Dampak ekstrakurikuler bagi siswa di MAN 3 Malang adalah berkembangnya sisi kepribadian siswa dan di SMAN 10 Malang Leadership Academy yaitu berkembangnya potensi kepemimpinan siswa.

Fika (2015) dengan judul penelitian Manajemen Kesiswaan Untuk Meningkatkan Motivasi Belajar Siswa Kelas VIII MTs Al-Islam Jono Bayan Purworejo Jawa Tengah. Penelitian ini merupakan penelitian kualitatif dengan metode pengumpulan data dengan interview, observasi, dan dokumentasi. Hasil penelitian menunjukkan bahwa manajemen kesiswaan mengatur siswa untuk meningkatkan motivasi belajar siswa, mulai dari penerimaan siswa, pembinaan serta kegiatan ekstrakurikuler. Guru sebagai motivator dituntut untuk kreatif, inovatif, dan dapat mengikutsertakan peran aktif siswa dalam proses pembelajaran.

\section{METODE PENELITIAN}

\section{Jenis Penelitian}

Implementasi Manajemen Kesiswaan dalam Meningkatkan Prestasi Siswa MA Unggulan Mamba'ul Huda Krasak Tegalsari Banyuwangi

Moh. Harun Al Rosid, Istiqomah 
Jenis penelitian yang digunakan dalam penelitian ini adalah jenis kualitatif deskriptif. Pada penelitian ini, peneliti mengkonsentrasikan pada implementasi manajemen kesiswaan dalam meningkatkan prestasi siswa di MA Unggulan Mamba’ul Huda Krasak Tegalsari Banyuwangi.

\section{Lokasi Penelitian}

Penelitian ini dilakukan di MA Unggulan Mamba'ul Huda Krasak Tegalsari Banyuwangi.

\section{Sumber Data}

Pada penelitian ini sumber data terdiri dari sumber data primer dan sumber data sekunder. Adapun data primer sekaligus informan dalam penelitian ini adalah Kepala MA Unggulan Mamba'ul Huda Krasak Tegalsari Banyuwangi dan WKM Kesiswaan Madrasah Aliyah Unggulan Mamba'ul Huda Krasak Tegalsari Banyuwangi. Sedangkan data sekunder didapat dari bagian tata usaha untuk mendapatkan data terkait administrasi dan data pendukung penelitian lainya.

\section{Teknik Pengumpulan Data}

Dalam penelitian ini menggunakan tiga teknik pengumpulan data, yaitu :

1) Teknik observasi dimana peneliti ikut berperan serta dalam mengamati hal-hal yang berkaitan dengan tema penelitian; 2) teknik wawancara; serta 3) dokumentasi.

\section{Teknik Analisis Data}

Miles and Huberman (1984) dalam Sugiyono (2019:321) mengemukakan bahwa aktivitas dalam analisis data kualitatif dilakukan secara interaktif dan berlangsung secara terus menerus sampai tuntas, dengan langkahlangkah analisis data berikut ini: 1) reduksi data; 2) penyajian data; seta 3) penarikan kesimpulan.

\section{HASIL PENELITIAN}

1. Data Tentang Pelaksanaan Manajemen Kesiswaan di MA Unggulan Mamba'ul Huda Krasak Tegalsari Banyuwangi

1. Perencanaan Penerimaan Siswa Baru

Implementasi Manajemen Kesiswaan dalam Meningkatkan Prestasi Siswa MA Unggulan Mamba'ul Huda Krasak Tegalsari Banyuwangi

Moh. Harun Al Rosid, Istiqomah 
Dalam perencanaan penerimaan siswa baru ini langsung dikelola oleh panitia penerimaan siswa baru. Mulai dari merumuskan target jumlah siswa yang akan diterima hingga mempersiapkan kebutuhan-kebutuhan dalam penerimaan siswa baru.

2. Orientasi Siswa Baru

Dalam orientasi siswa baru di MA Unggulan Mamba'ul Huda Krasak Tegalsari, baik siswa dan orang tua akan dikenalkan dengan lingkungan madrasah yang berada di bawah naungan pondok pesantren. harapanya setelah dikenalkan siswa dapat beradaptasi dengan baik terhadap lingkungan madrasah yang baru.

3. Pengelompokan Siswa Baru

Pengelompokan siswa baru di MA Unggulan Mamba'ul Huda Krasak Tegalsari dimulai pada saat siswa mendaftarkan diri. Pada saat pendaftaran, dilakukan interview bersama dengan orang tua calon siswa baru. Interview ini berkaitan dengan jurusan yang akan dipilih oleh calon siswa.

4. Kegiatan Pembinaan kesiswaan dalam meningkatkan prestasi siswa Dalam implementasi manajemen kesiswaan pembinaan kegiatan siswa adalah hal yang paling penting. Pembinaan kegiatan siswa ini berkaitan dengan prestasi siswa, baik akademik dan non akademik. pembinaan kegiatan akademik adalah kegiatan yang berkaitan dengan pembelajaran siswa yang telah ditentukan pada kurikulum. Sedangkan kegiatan non akademik siswa dilaksanakan diluar jam pelajaran atau tidak terjadwal dalam kurikulum.

5. Evaluasi Kegiatan Siswa MA Unggulan Mamba'ul Huda Krasak Tegalsari

Evaluasi kegiatan siswa dilakukan dalam rangka melihat perkembangan dan kemampuan siswa setelah dilakukan pembelajaran. Dalam mengevaluasi kegiatan siswa perlu adanya kordinasi dari seluruh tenaga pendidik, baik kepala madrasah hingga dewan guru. Selain dalam ujian semester, evaluasi di MA Unggulan Mamba’ul Huda Krasak Tegalsari 
JMPID ( Jurnal Manajemen Pendidikan Islam Darussalam )

Jurnal Manajemen Pendidikan Islam

Volume: 2, No: 2, September 2020 ISSN : 2722-7146 (online)

dilakukan setiap satu minggu satu kali dengan mengadakan rapat bersama.

\section{Data Tentang Prestasi Siswa MA Unggulan Mamba'ul Huda Krasak} Tegalsari Banyuwangi

Sebagai upaya dalam meningkatkan prestasi siswa dan juga sebagai upaya pemenuhan harapan dari orang tua siswa, maka MA Unggulan Mamba'ul Huda Krasak Tegalsari sangat selektif dalam proses rekrutmen siswa baru dengan system penjaringan siswa berprestasi baik dalam ilmu pengetahuan (pengetahuan akademik) maupun minat bakat (non akademik). Dalam mengembangkan prestasi akademik MA Unggulan Mamba'ul Huda Krasak Tegalsari.

\section{Faktor Pendukung dan Penghambat Manajemen Kesiswaan Dalam} Meningkatkan Prestasi Siswa MA Unggulan Mamba'ul Huda Krasak Tegalsari Banyuwangi

Kualifikasi tenaga pendidik dan kependidikan di MA Unggulan Mamba'ul Huda Krasak Tegalsari juga sesuai dengan keahlian atau kelinearan serta bertanggung jawab atas tugasnya masing-masing. Kelengkapan Sarana dan prasarana dalam penunjang proses pembelajaran juga menjadi daya tarik sendiri bagi siswa, sehingga siswa tidak hanya mendapatkan materi di dalam kelas, tetapi juga bisa langsung praktek. Sedangkan faktor penghambat manajemen kesiswaan dalam meningkatkan prestasi siswa MA Unggulan Mamba'ul Huda Krasak Tegalsari adalah terkait dengan waktu. karena mayoritas siswa bermukim di asrama.

\section{E. PEMBAHASAN}

1. Pelaksanaan Manajemen Kesiswaan di MA Unggulan Mamba'ul Huda Krasak Tegalsari

a. Perencanaan penerimaan siswa baru mencakup jumlah siswa yang akan diterima, menentukan syarat-syarat penerimaan siswa baru, melaksanakan penyaringan, serta melakukan pelaporan kepada kepala madrasah yang semua ini direncanakan pada satu tahun sebelum pelaksanaan penerimaan siswa baru.

Implementasi Manajemen Kesiswaan dalam Meningkatkan Prestasi Siswa MA Unggulan Mamba'ul Huda Krasak Tegalsari Banyuwangi

Moh. Harun Al Rosid, Istiqomah 
b. Orientasi siswa baru dilakukan selama tiga hari dalam rangka mengenalkan siswa tehadap lingkungan madrasah, baik secara fisik maupun kebiasaan-kebiasaan madrasah.

c. Pengelompokan siswa baru dilakukan dalam berbagai tahap, yaitu pengelompokan berdasarkan jurusan yang dipilih, pengelompokan berdasarkan jenis kelamin, dan pengelompokan berdasarkan dengan potensi atau prestasi siswa..

d. Pembinaan kegiatan siswa baik akademik maupun non akademik dilakukan dalam meningkatkan prestasi siswa. Pembinaan kegiatan akademik dilakukan pada saat jam pelajaran, sedangkan pembinaan kegiatan non akademik dilakukan diluar jam pelajaran.

e. Evaluasi Kegiatan Siswa MA Unggulan Mamba'ul Huda Krasak Tegalsari

Dalam mengevaluasi kegiatan siswa MA Unggulan Mamba'ul Huda Krasak Tegalsari dilaksanakan dengan ujian semester. Dalam ujian semester ini yang dievaluasi adalah terkait dengan kegiatan akademik. Sedangkan evaluasi dalam kegiatan non akademik dilaksanakan dalam satu minggu satu kali.

\section{Prestasi Siswa MA Unggulan Mamba'ul Huda Krasak Tegalsari}

a. Prestasi akademik pada siswa MA Unggulan Mamba'ul Huda Krasak Tegalsari secara umum dari tahun ke tahun terus meningkat, dalam ujian semester atau ujian kenaikan kelas tidak ada siswa yang tidak naik. Pun pada saat Ujian Nasional tidak ada siswa yang tidak lulus. Dan setiap lulusanya dapat langsung bekerja atau juga dapat melanjutkan kuliah ke perguruan tinggi.

b. Prestasi non akademik, merupakan prestasi yang diraih oleh siswa melalui pembinaan kegiatan non akademik. Bentuk dari kegiatan non akademik di Madrasah Aliyah Mamba’ul Huda Krasak Tegalsari adalah olahraga, pramuka, hydroponic, videografi, dan lain sebagainya.

\section{Faktor Pendukung dan Penghambat Manajemen Kesiswaan dalam} Meningkatkan Prestasi Siswa MA Unggulan Mamba'ul Huda Krasak Tegalsari

Implementasi Manajemen Kesiswaan dalam Meningkatkan Prestasi Siswa MA Unggulan Mamba'ul Huda Krasak Tegalsari Banyuwangi

Moh. Harun Al Rosid, Istiqomah 
a. Faktor pendukung: 1) sarana dan prasarana pendidikan yang memadai; 2) semangat belajar siswa yang tinggi; 3) tenaga pendidik profesional 4) tenaga pendidik dan kependidikan merupakan alumni dari pondok pesantren.

b. Faktor penghambat: 1) mayoritas siswa MA Unggulan Mamba'ul Huda Krasak Tegalsari merupakan santri yang menetap di asrama, siswa hanya dapat mengembangkan diri pada jam-jam tertentu karena harus membagi waktu dengan kegiatan di asrama; 2) masih terdapat beberapa siswa yang kurang disiplin.

\section{F. KESIMPULAN}

\section{Pelaksanaan Manajemen Kesiswaan di MA Unggulan Mamba'ul Huda Krasak Tegalsari}

Pelaksanaan manajemen kesiswaan di MA Unggulan Mamba'ul Huda Krasak Tegalsari meliputi : (1) perencanaan penerimaan siswa baru dilakukan satu tahun sebelumnya (2) orientasi siswa baru diselenggarakan selama 3 hari dengan mengenalkan lingkungan madrasah, baik lingkungan fisik ataupun kebiasaan-kebiasaan madrasah.4) pembinaan kegiatan intrakurikuler (akademik) dilakukan dengan memberikan pelajaran tambahan dalam bentuk club. (5) pembinaan kegiatan ekstrakurikuler (non akademik) dilaksanakan melalui pengembangan bakat minat (6) Evaluasi Kegiatan Siswa dilakukan dengan dengan dua cara, yaitu evaluasi akademik dengan ujian semester dan evaluasi non akademik dengan rapat bersama dalam satu minggu satu kali.

\section{Prestasi Siswa MA Unggulan Mamba'ul Huda Krasak Tegalsari}

Dari pembinaan kegiatan intrakurikuler (akademik) terbukti bahwa siswa MA Unggulan Mamba'ul Huda Krasak Tegalsari dapat mengikuti kejuaraan tingkan regional yaitu pada Stikes Banyuwangi English Competition dengan jenis perlombaan story telling dan presentation skill. Prestasi akademik pada siswa MA Unggulan Mamba'ul Huda Krasak Tegalsari secara umum dari tahun ke tahun terus meningkat, dalam ujian semester atau ujian kenaikan kelas tidak ada siswa yang tidak naik kelas. Implementasi Manajemen Kesiswaan dalam Meningkatkan Prestasi Siswa MA Unggulan Mamba'ul Huda Krasak Tegalsari Banyuwangi Moh. Harun Al Rosid, Istiqomah 
Pun pada saat Ujian Nasional tidak ada siswa yang tidak lulus. Dan setiap lulusanya dapat langsung bekerja atau juga dapat melanjutkan kuliah ke perguruan tinggi. Selain prestasi akademik, siswa MA Unggulan Mamba'ul Huda Krasak Tegalsari juga mengembangkan diri pada bidang non akademik, salah satunya pada bidang pramuka yang salah satu anggotanya dapat mewakili PASKIBRA di Kabupaten.

\section{Faktor Pendukung dan Penghambat Manajemen Kesiswaan dalam} Meningkatkan Prestasi Siswa MA Unggulan Mamba'ul Huda Krasak Tegalsari

a. Faktor pendukung: 1) sarana dan prasarana pendidikan yang memadai; 2) semangat belajar siswa yang tinggi; 3) tenaga pendidik profesional 4) tenaga pendidik dan kependidikan merupakan alumni dari pondok pesantren.

b. Faktor penghambat: 1) mayoritas siswa MA Unggulan Mamba'ul Huda Krasak Tegalsari merupakan santri yang menetap di asrama, siswa hanya dapat mengembangkan diri pada jam-jam tertentu karena harus membagi waktu dengan kegiatan di asrama; 2) masih terdapat beberapa siswa yang kurang disiplin.

\section{G. Daftar Pustaka}

Hamdani. 2011. Strategi Belajar Mengajar. Bandung: Pustaka Setia.

Mantja, W. 2007. Profesionalisasi Tenaga Kependidikan, Manajemen Pendidikan Dan Supervisi Pengajaran. Malang: Elang Mas.

Mulyasa. 2005. Manajemen Berbasis Sekolah:Konsep, Strategi, Dan Implementasi. Bandung: Remaja Rosda Karya.

Mulyono. 2008. Manajemen dan Organisasi Pendidikan. Yogyakarta: ArRuzz.

Prihatin, Eka. 2011. Manajemen peserta didik. Bandung: Alfabeta.

Sugiyono. 2019. Metode Penelitian Kuantitatif, Kualitatif, dan R\&D. Bandung : Alfabeta.

Supriatna, Mamat. 2010. Pendidikan Karakter Via Ekstrakurikuler. Bandung : PT Remaja Rosdakarya.

Implementasi Manajemen Kesiswaan dalam Meningkatkan Prestasi Siswa MA Unggulan Mamba'ul Huda Krasak Tegalsari Banyuwangi

Moh. Harun Al Rosid, Istiqomah 
Syaiful Bahri Djamarah. 2002. Prestasi Belajar dan Kompetensi Guru. Surabaya: Usaha Nasional.

Tulus, Tu'u. 2004. Peran Disiplin pada perilaku dan prestasi belajar. Jakarta : Grasindo.

Undang-Undang Republik Indonesia Nomor 20 Tahun 2003 tentang Sistem Pendidikan Nasional. 2005. Jakarta: PT Armas Duta Jaya. 